\title{
Psikiyatri Hemşireliği Alanında Önemli Bir Yapı: Aile Dayanıkııı̆ı
}

\author{
Zekiye ÇETINKAYA DUMAN ${ }^{1}$, (D)Ayşe SARI ${ }^{2}$
}

${ }^{1}$ Prof· Dr., Dokuz Eylül Üniversitesi, Hemşirelik Fakültesi, Psikiyatri Hemşireliği Anabilim Dalı, İzmir, Türkiye ${ }^{2}$ Dr., İzmir, Türkiye

\section{Öz}

Aile dayanıklılığı kavramı, bir sistem olarak ailenin yaşamış olduğu güçlüklere karşı koyma ve toparlanma becerisi olarak tanımlanmaktadır. Bireysel dayanıklılıktan farklı olarak aile dayanıklılı̆̆ı sistemsel bir bakış açısı ile aile üyelerinin ayrı ayrı dayanıklılık özelliklerine değil, sistem olarak ailenin dayanıklılığına odaklanmaktadır. Aileye dayanıklılık kazandıran üç anahtar dayanıklılık süreci tanımlanmıştır. Bunlar “Aile İnanç Sistemleri”, “Organizasyon (Örgüt) Kalıpları” ve “İletişim/Problem Çözme Süreçleri” dir. Özellikle ailelerle çalışan hemşirelerin bu dayanıklılık süreçlerini güçlendirecek aile müdahaleleri planlamaları ailelerin kriz durumları ile başetmesinde yardımcı olacağı düşünülmektedir.

Anahtar Sözcükler: Aile Dayanıklılığı, Anahtar Süreçler, Psikiyatri Hemşireliği.

Geliş Tarihi / Received: 22.06.2020 Kabul Tarihi / Accepted: 22.04.2021

Correspondence Author: Prof. Dr., Dokuz Eylül Üniversitesi, Hemşirelik Fakültesi, Psikiyatri Hemşireliği Anabilim Dalı, İzmir, Türkiye.. Telefon: +90 232 4124784 E-posta: zekiyecetinkaya69@gmail.com

Cite This Article: Çetinkaya Duman Z, Sarı A. Psikiyatri Hemşireliği Alanında Önemli Bir Yapı: Aile Dayanıklılığı Dokuz Eylül Üniversitesi Hemşirelik Fakültesi Elektronik Dergisi. 2021; 14(3): 268- 276 
$\mathbf{H}$ er birey ve aile kendi yaşam döngüsü içerisinde güçlük ve kriz durumları ile karşı karşıya kalabilmektedir. Yaşanan problem ya da güçlükler birey ve ailenin işlevselliğinde etkilenmeye yol açabilir. Bu süreç aile ve ilişki dinamiklerini olumsuz etkileyebileceği gibi, birey ve ailenin bu süreçten güçlenerek çıkması ile de sonuçlanabilmektedir (1). "Riskli ya da olumsuz yaşam koşullarında neden bazı bireyler işlevsel ya da sağlıklı kalabiliyorken, neden bazı bireyler kalamıyor?" sorusunun yanıtı bugün yürütülen dayanıklılık çalışmalarının temelini oluşturmuştur (2). Dayanıklılık kavramı ile ilgili birç̧ok tanımlama yapılmıştır. Dayanıklılık kavramı; "zorluklara rağmen kendini toparlama kapasitesi”” olarak tanımlanmaktadır $(3,4,5)$. Başka bir tanıma göre dayanıklılık, "dinamik bir sistemin işlevini, hayatta kalmasını ve gelişimini tehdit eden her türlü karışıklığa başarılı bir şekilde uyum sağlama potansiyelidir". Bu tanım bir bireyin dayanıklılığından, bir ailenin ya da toplumun dayanıklılığına kadar her türlü canlı ve dinamik sisteme uyarlanabilmektedir (6). Aile dayanıklılığ kavramı ise, "bir işlevsel sistem olarak ailenin yaşamış olduğu güçlüklere karşı koyma ve toparlanma becerisi” olarak tanımlanmaktadır (5). Dayanıklılık sonuç ile ilgili değil, süreçle ilgili bir kavram olduğu için bir bireyi "dayanıklı birey" olarak değerlendirmek yerine "dayanıklılık özellikleri sergileyip sergilemediğini” değerlendirmek daha doğru bir yaklaşım olacaktır (7).

"Sağlıklı aile" kavramı dendiğinde genellikle kökenini tıbbi modelden alan "sorunları olmayan aile" kavramı akla gelmektedir. Fakat her aile birtakım sorunlar yaşamaktadır ve sorunsuz aile bulunmamaktadır (8). Geleneksel bakış açısı ailenin problemlerinin altında aile patolojisi ararken, dayanıklılık bakış açısından ailenin probleminin nedeni başarılı olamayan çözüm girişimleridir (9). Aile dayanıklılığı ailenin hangi yaşam aşamasında olduğu ile yakından ilişkilidir. Çünkü aynı güçlük ya da yaşamsal zorluğun üstesinden gelmek için içinde bulunduğu dönemde gücünü kullanabilen aynı aile, başka bir yaşam döneminde bu girişiminde başarılı olamayabilir. Bu durum ailenin dayanıklılı̆̆ olmadığı anlamına gelmemektedir. Dayanıklılık statik değil, dinamik bir kavramdır ve her ailenin dayanıklılığa giden yolları kendine özgüdür (10). Bu derlemenin amacı, aile dayanıklılığı kavramının farklı bakış açılarından ele alınması, aile dayanıklılığı süreçlerinin ve psikiyatri hemşireliğine yansımasının açıklanmasıdır.

\section{Aile Dayanıklılı̆̆ Kavramının Gelișimsel Süreci}

\section{Gelişme}

Ailelerle yürütülen çalışmaların tarihsel sürecinde, ailelerde odaklanılan özellikler zaman içerisinde değişim göstermiștir. Odaklanılan konular 1970'li yıllara kadar ailedeki patoloji üzerinedir (11). Aile alanında 1970'li yıllardan sonra özellikle McCubbin ve arkadaşlarının (1983) ailenin kriz ve başetme süreci ile ilişkili çalışmaları paradigmal bir değişim sunmuştur. Bu bakış açısına göre yenileyici güç kavramını ortaya koyan bir aile krizi çerçevesi geliştirmişlerdir (12). Bu bakış açısı aynı zamanda aile çalışmalarında da paradigmal değişimi beraberinde getirmiş̧tir. Dayanıklılık bakış açısından ailelerin krize neden olabilecek sorunlu yönlerine odaklanmak yerine, güçlü, iyileştirilebilir yönlerine odaklanmaya doğru bir değişim meydana gelmiştir $(5,13)$.

Psikososyal alanda dayanıklılık kavramı ilk aşamada birey ile ilişkilendirilmiş ve dayanıklılık kavramının gelişim süreci üç dalga olarak ilerlemiştir $(14,15)$. Birinci dalga olarak belirtilen aşamayı çocuklar üzerinde yapılan dayanıklılık çalışmaları oluşturmuștur. Dayanıklılık konusunda çalışmalar yürüten ilk araștırmacılar çocukların kișilik özelliklerine odaklanarak çalışmalarını yürütmüşlerdir (16). Çalışmaların yürütüldüğü çocukları diğer çocuklardan ayıran özellikler yoksulluk, alkol kullanımı, ruhsal hastalık vb. gibi sorunları olan aileler ile büyüyen sosyal olarak dezavantajlı grubun içerisinde fakat işlevselliğini sürdüren ve "dayanıklılık" özelliği olan çocuklar olmalarıdır (17). Bu aşamada dayanıklı aile özellikleri belirlenip, aile sistemi düzeyinde bir yapı kurulmuştur (15). İkinci dalgada ise dayanıklılık sürecini kolaylaştıran koruyucu faktörlere odaklanan çalışmalar yürütülmüştür. İkinci dalga sürecinde genel sistem teorisi gibi kavramlar bireysel dayanıklılığa entegre edilmiştir (18). Risk faktörleri ve koruyucu faktörler kavramları bu dönemde ön plana çıkmıştır. Aile sistemine yapılan vurgu bu dönemde artmıştır. Üçüncü dalga ise dayanıklılığı artırmaya yönelik müdahalelerin yer aldığı aşamadır. Birinci ve ikinci aile dayanıklılı̆̆ dalgaları aile müdahalelerinde araştırma ve uygulamaların temelini oluşturmaktadır $(14,15)$. Şekil 1'de dayanaklılık kavramının gelişim süreci görülmektedir

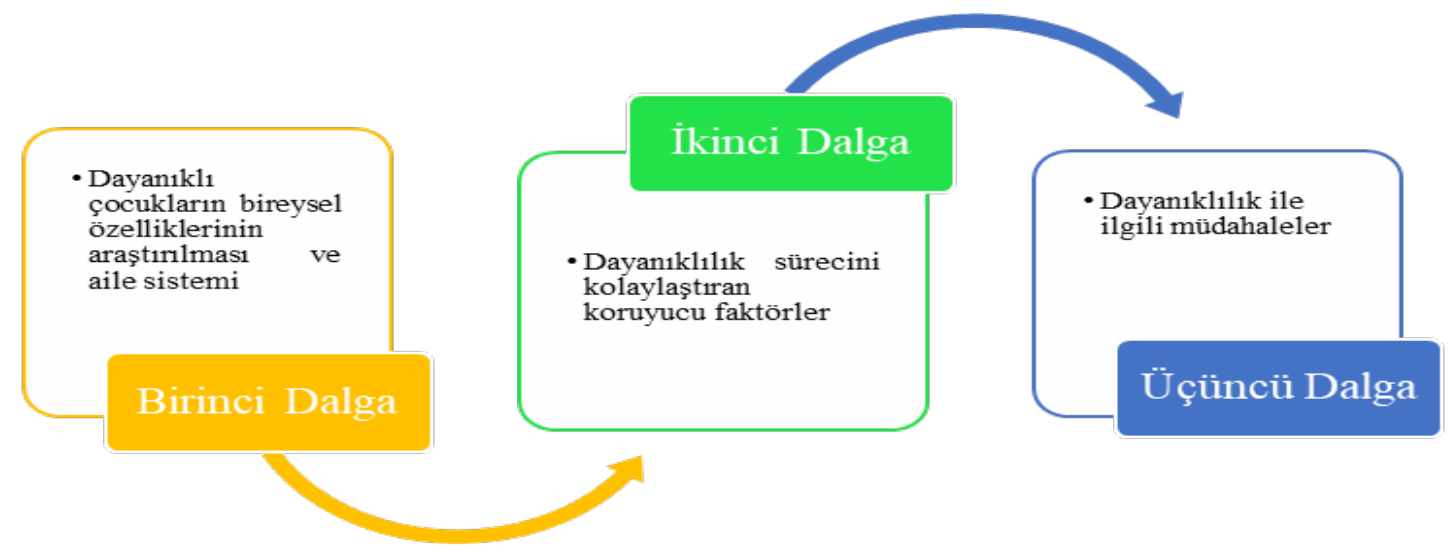

Şekil 1. Dayanıklılık kavramının gelişimi 


\section{Sistemik Bakış Açısından Aile Dayanıklılığı}

Aile dayanıklılığı sistem teorisinden köken almaktadır. Sistem teorisinde yer alan bazı ilkeler aynı zamanda aile dayanıklılığına entegre edilebilmektedir. Her canlı sistem tıpkı aile gibi dinamik yapıya sahiptir. Sistemler birbirine bağlıdır ve kendi aralarında enerji aktarımı söz konusudur. Ailenin kendi arasında ve çevresi ile olan bağlantıları, etkileşimleri tüm aile sistemini etkilemektedir. Sistemik bakış açısından bir sistemin dayanıklılığı bağlı olduğu diğer sistemin dayanıklılığına da bağlıdır (19). Dayanıklılık bir sistemden diğerine aktarılabilir olduğu için riskli bir durumla karşılaşan bir aileye dayanıklılık kazandırmak için hem aile üyelerinin hem de ailenin içerisinde yer alan toplumun güçlendirilmesi de önem kazanmaktadır (14).

"Aile üyelerinin dayanıklılı̆̆ı" ve "aile dayanıklılığı" kavramları birbiri ile ilişkili fakat birbirinden farklı kavramlardır. Her aile bir sistemdir ve sistemik bakış açısı, tek tek aile üyelerinin dayanıklılığından ziyade bir birim olarak ailede risk ve dayanıklılığa odaklanmaktadır (20). Geleneksel bakış açısına göre ailenin dayanıklılığı aile üyelerinin dayanıklılığının toplamına eşdeğer iken, güncel bakış açısı aile dayanıklılığını ailenin ilişkisel süreçlerinde aramaktadır (21). Bu nedenle özellikle ailelerle yürütülen çalışmalarda sistem olarak ailenin dayanıklılık özelliklerinin dikkate alınması önemlidir. Her aile üyesi birbirinden farklı özelliklerde olsalar da aile dayanıklılı̆̆na her üyenin katkısı bulunmaktadır (9).

Sistemik bakış açısı ile aile dayanıklılığına yalnız bireysel katkıların değil, ailenin bir bütün olarak iletişim, ilişkiler, dinamikler boyutuyla katkısı öne çıkmaktadır. Dayanıklılığın, aile içerisindeki ilişkiler, etkileşimler ve paylaşım örüntülerinde (17), olumlu destek bağlantıları, paylaşımlar ve deneyimler örüntüsünde oluştuğu belirtilmektedir (22). Oh ve Chang (2014) aile dayanıklılığı konusunda yapmış oldukları kavram analizi çalışmasında aile dayanıklılı̆̆ının altı özelliğinin olduğunu belirtmiş̧ir. Bu özellikler; ortak güven, bağlılık, yaşama pozitif bakış açısı, algılanan destek (desteğe ulaşma becerisi), açı iletişim örüntüleri ve işbirlikçi problem çözmedir. Çalışma sonucunda, aile dayanıklılığı kavramına ilişkin çıktılar ise durumu kabullenme, yaşama bakış açısının değişmesi, yaşam kalitesinde artma, dayanıklılık özelliklerinde artma ve sağlıkla ilişkili sonuçlar olarak beş başlıkta toplanmıştır (21).

Bir ailenin dayanıklılı̆ıı, ailenin stres ve başetme süreçleri ile de yakından ilişkilidir. Patterson (2000)'un aile stresi ve başetme teorisine dayalı Aile Uyum ve Uyuma Yanıt Modeli (Family Adjustment and Adaptation Response, FAAR) bir sistem olarak aile dayanıklılı̆̆ını açıklamada kullanılan temel modellerden biridir. Bu modelin temel kavramları ailenin "risk faktörleri (talepleri)", "ailenin koruyucu faktörleri (yetenekleri)" ve "anlamdır". Bu "anlamlar" ailenin risk faktörleri ve koruyucu faktörlerini nasıl anlamlandırdıkları ile ilişkilidir. Ailenin risk faktörleri ile ailenin koruyucu faktörleri iki karşılıklı uçta duran bir terazi gibi düşünülebilir. Dengeyi sağlayan yapı ise aile için hem risk hem de koruyucu faktörlerin doğasını şekillendirmektedir. Bu denge, ailede risk faktörleri artış gösterdiğinde bozulmaktadır ve "kriz" durumu görülmektedir. Eğer aile kaynaklarını zenginleştirerek riski azaltmayı başarabilirse bu durumun tam tersi de mümkün olabilmektedir. Ortaya çıkan yeni durum ise aile için "yenileyici/rejeneratif güçc" olarak tanımlanmaktadır. Ailenin dayanıklılığı bu "yenileyici" güce benzetilebilir $(2,23)$.

\section{Aile Dayanıklılı̆̆ında Anahtar Süreçler}

Aile dayanıklılığının bir boyutu olarak; ailenin deneyimlemiş olduğu güçlüğün düzeyi önemlidir. Eğer yaşanan güçlük uzun süreli ise, yaşanan durum "kriz" e dönüşebilmektedir ve uzun dönemli bu güçlükler bir düzenleme sürecini gerektirmektedir (9). Aile dayanıklılığını anlamada ailenin gelişimsel bakış açısı ile ele alınması gerekmektedir (20). Aile için krizler tıpkı bir uyandırma zili gibi düşünülebilir. Bu süreçte ailenin önceliklerini yeniden gözden geçirmesi, ilişkilere daha fazla yatırım yapması için krizler bir firsat da sunabilmektedir (24). "Kriz" ifadesinin Çince' de iki sembolü içerisinde barındırdığı belirtilmektedir. Bunlardan ilki "tehdit" iken, diğeri ise "meydan okuma" dır $(8,17)$.

Güçlüklerle ya da kriz durumları ile karşı karşıya kalındığında ailenin buna yaklaşımı oldukça önemlidir. Ailelerin kriz durumlarından güçlenerek çıkmasını sağlayan ve her ailenin dinamiklerine uyan tek tip bir dayanıklılık modeli bulunmamaktadır. Her aile kendi dayanıklılık sürecinde kendi yolculuğuna çıkmaktadır. Fakat bu yolda süreci kolaylaştıran anahtar süreçler bulunmaktadır (22). Anahtar süreçler ailenin bu zor zamanlardan daha rahat toparlanmasını ve olumlu yönde uyumunu sağlamayı kolaylaştıran süreçlerdir. Walsh (2003) aile dayanıklılığında üç anahtar süreç tanımlamıştır. Fakat bu tanımlanan anahtar süreçleri “dayanıklı aile özellikleri” olarak düşünmek yerine, ailenin dayanıklılığını artıran güç ve kaynaklar olarak düşünülebilir (8). Bu anahtar değişkenleri birbiri ile etkileşim halindedir (Tablo 1).

Tablo 1. Aile Dayanıklılı̆̆ Anahtar Süreçleri

\begin{tabular}{ll}
\hline Aile İnanç Sistemleri & Güçlüklerin Anlamı \\
& Olumlu Bakış Açısı \\
& Aşkınlık ve Maneviyat \\
\hline Organizasyon (Örgüt) Kalıpları & Esneklik \\
& Bağl1lık \\
& Sosyal ve Ekonomik Kaynaklar \\
\hline İletişim/Problem Çözme Süreçleri & Açıklık \\
& Açı Duygusal Paylaşım \\
& İşbirlikçi Problem Çözümü \\
\hline (Kaynak: Walsh F. Family resilience: a framework for clinical practice. Fam process 2003;42(1): 1-18)
\end{tabular}

Aile İnanç Sistemleri: İnançlar, bireylerin olduğu gibi ailelerin de yaşama bakış açısını şekillendiren merceklere benzetilmektedir. Nasıl bir insan olduğumuz, yaşam deneyimlerimizi nasıl anlamlandırdığımız inançlarla doğrudan ilişkilidir 
(17). Aile inanç sisteminin içerisinde üç temel parametre yer almaktadır. Bunlar; güçlüklerin anlamı, olumlu bakış açısı ve aşkınlık ve maneviyattır $(5,20,24)$.

Güçlüklerden Çıkarılan Anlam: Yıkıcı, zor ve beklenmedik bir durumla karşılaşan ailenin karşı karşıya kaldığı bu durumun anlamlarını yeniden oluşturma ihtiyacı da doğacaktır. İyileşme sürecinde ailelerin bu anlam oluşturması oldukça elzemdir (25). Ailelerin anlamlandırma sürecini kolaylaştırmada, aile üyelerinin durumlarını gerçekçi bir şekilde değerlendirmesi ve durumla aktif başa çıkmaları desteklenmelidir (24).

Olumlu Bakış Açısı: Ailenin olumlu bakış açısı yaşanan güçlükler ve stresle başetmesinde oldukça önemlidir. Bu bakış açısı içinde "umut” önemli bir yer tutmaktadır. Yaşam için oksijenin anlamı ne ise, ruh için de umudun anlamı buna benzetilmektedir. Umut da inanca dayanmaktadır. "Olabilir, yapılabilir" inancı ve umudu ailenin dayanıklılığında oldukça temel bir düşüncedir $(5,24)$.

Aşkınlık ve Maneviyat: Maneviyat (spiritüalite) aile dayanıklılığında temel kavramlardan biridir. Ailenin paylaşılan inanç ve değerleri aileyi aynı doğrultuda hareket etmeye ve aynı hedefe yönlendirmektedir (21).

Organizasyon Kalıplart: Bu süreçte yer alan yapılar ailelerin zor durumlarda bir araya gelmesini düzenleyen yapılardır (5).

Esneklik: Esneklik, uyum sağlama, uyumsal (adaptif) değişimi içeren temel ögelerden biridir. Ailelerin kriz durumları ile karşılaşması durumunda, kriz öncesi duruma dönüş tam anlamıyla sağlanamayabilir. Bu durumda ailenin esneklik özelliği ailenin "yeni normal" ini kazanabilmesine yardımcı olmaktadır. Örneğin, ailede kronik bir hastalık tanısı alan üyenin olması, evden bir üyenin ayrılması ya da kaybı buna örnek verilebilir. Bu yeni durumlar aynı zamanda yeni uyumu gerektiren krizlere dönüşebilmektedir. Koruyucu bir yapı olarak esneklik özelliği yeni duruma uyumu sağlamaktadır $(5,17)$.

Bağlılık: Kriz durumlarında ailenin dayanıklılığını güçlendiren süreçlerden birisi de aile bağlılığıdır. Çünkü süreçte her üyenin yaşanan duruma tepkisi farklılık gösterebilir. Zor zamanlarda üyelerin kendilerine değil, birbirlerine dönük olması, karşılıklı paylaşımlar ve işbirliği bu süreci güçlendiren önemli etmenlerdendir.

Sosyal ve Ekonomik Kaynaklar: Ailelerin sosyal ve ekonomik kaynaklara erişiminin sağlanması dayanıklılık için oldukça önemlidir. Örneğin, ruhsal hastalık tanılı bireyin bakım giderleri aileyi ekonomik olarak zorlayabilir. İzole bir yaşam yerine aileler toplumsal kaynaklara yönlendirilmelidir (5).

Iletişim/Problem Çözme Süreçleri: Açık ve tutarlı mesajlar, açık duygusal ifade ve işbirlikçi problem çözümü bu sürecin içerisinde yer alan basamaklardır.

Açıklık: İyi bir iletişim, bireyler arasında duygu, düşüncenin iletilmesinin ve ilişkilerin şekillenmesinin temel yapı taşıdır. Yalnızca sözlü değil, sözsüz ifadeler de bu süreçte oldukça önemlidir. Özellikle ailelerin kriz durumlarında yanlış anlamalarının önüne geçmek, üyelerin kendilerini doğru bir biçimde ifade edebilmelerinde açık bir iletişim, bir gerekliliktir (17).

Açık Duygusal Paylaşım: Açık bir iletişim, empati ve güven ortamı sağlandığında aile üyelerinin duygularını da açık bir biçimde paylaşmalarını kolaylaştırıcı bir ortam sağlanmaktadır. Çünkü yoğun duygular, açık ve doğru biçimde ifade edilmediğinde yıkıcı sonuçlar ortaya çıkarabilmektedir. Bunu önlemenin yolu üyelerin birbirini dinlemesi, karş1lıklı saygı ve güven ile doğru biçimde duygularını açıkça ifade edebilecekleri bir paylaşım ortamının sağlanmasıdır $(5,17,26)$.

İşbirlikçi Problem Çözümü: Her ailenin, her bireyin sorun yaşadığı zamanlar olmaktadır. Yaşamın içerisinde bu sorunları göz ardı etmek ya da sorunları üstlenmeyip karşı tarafı suçlamak yerine, sorunlardan bir takım öğretiler çıkarmak ve çözüme odaklanmak dayanıklılık sürecinde kazanılan oldukça önemli bir beceridir. Sorunun çözümüne giden birçok yol bulunmaktadır ve her ailenin çözüm yolları, bu yoldaki kaynakları kendine özgüdür $(5,17,26)$.

\section{Aile Dayanıklılığı ve Psikiyatri Hemşireliği}

Geçmişten günümüze aile dayanıklılığı konusunda yapılan çalışmalar, ailelerin zayıf, problemli yönleri yerine kendi aile sistemi içerisindeki ilişkilerin dinamiklerinde oluşan dayanıklılık süreçlerine odaklanması ve ailenin güçlü yönlerine dikkat çekmesi açısından oldukça önemlidir. $\mathrm{Bu}$ bakış açısı aynı zamanda ailelere ve aileleri güçlendirmeye yönelik müdahalelerin oluşturulmasına da temel oluşturmaktadır (21). Psikiyatri hemşireleri birey, aile ve toplumun sağlı̆̆ının korunması ve geliştirilmesi noktasında önemli bir pozisyonda yer almaktadır. Toplumun en temel birimi olan aile, hemşirelerin önemli müdahale alanlarından birini oluşturmaktadır. Ailelerle işbirliğinin desteklenmesi, karşılıklı destek ailelerin paylaşılmış bir güven ortamı elde etmelerine katkı sağlamaktadır. Bu da ruh sağlığı hizmetlerinde ailelerin sürece dâhil edilmesi, ailelerle iş birliği kurulması ve bir hizmet anlayışı olarak ailelerin süreçte yer almasını gerektirmektedir (27).

Aile dayanıklılığı bakış açısı psikiyatri hemşireliği uygulamalarına da 1şık tutmaktadır. Psikiyatri hemşirelerinin bakım verdikleri hastaları yalnızca "patoloji” ya da "hastalık" bakış açısından görmek yerine bir ailenin ve bir toplumun parçası olarak bütüncül ele almaları, "büyük resmi” görmeleri açısından oldukça önemlidir. Hasta bireyler ailenin, aileler ise toplumun bir yansıması olarak düşünülebilir. Bu nedenle bireyleri tek tek ele almaktan öte, "aile dayanıklılığı” bakış açısı bir sistem olarak bütün bir biçimde ailenin dayanıklılık özelliklerine odaklanmaktadır. Bu yönüyle dayanıklılık bakış açısı, her ailede mevcut olan fakat kriz durumlarında fark edilmeyen güçlü yanları ortaya çıkarma, ailenin mevcut potansiyelini ortaya koyabilmesini desteklemede hemşirelere önemli sorumluluklar yüklemektedir. Ailelerin inanç sistemlerinde yer alan anlamları fark ettirme, aileye esneklik özellikleri kazandırma girişimleri, destek kaynakları açısından aileleri güçlendirme, ailelerin problem çözme becerilerini geliştirme ve destekleme, sorunlara olan bakış açısını fark etmesini sağlama dayanıklılık sürecinde yer alan basamaklardan ailelere uygulanabilecek bazı hemşirelik girişimlerine örnek olarak verilebilir. Hasta birey ve ailesine uygulanan 
dayanıklılığı geliştirmeye yönelik bu müdahaleler sistemin parçası olan toplumu da etkilemektedir. Bu yönüyle ailelerde dayanıklılığı sağlamaya yönelik yürütülen değerlendirme ve müdahalelerin, bir anlamda toplumda dayanıklı yapılar oluşturmaya katkı sağladığı söylenebilir (1).

Planlı aile müdahaleleri psikososyal bir müdahale olarak ruhsal sağlık sorunu yaşayan ailelerin güçlendirilmesi noktasında önemli bir role sahiptir (28). Özellikle ailelerdeki dayanıklılık özelliklerinin incelenerek bu dayanıklılık özelliklerinin müdahale programlarının içeriğine dâhil edildiği aile müdahalelerinin planlanması da aileleri güçlendirmede oldukça önemlidir. Çoklu aile psikoeğitim grupları ve kendi kendine yardım gruplarının özellikle aile dayanıklılığını geliştirmede etkili olduğu belirtilmektedir (4). Dayanıklılık, benzer zorluklarla uğraşan diğer ailelerle temas yoluyla ve birbirlerinden öğrenilerek de kazanılabilmektedir. Bu nedenle ailelerle çalışılırken, aynı sorunu yaşayan benzer grupların bir arada olmasını sağlayacak ortamların oluşturulması önerilmektedir. Bu amaca hizmet etmede aileden aileye destek/eğitim programları önemli ve etkili müdahaleler olarak örnek verilebilir $(28,29)$. Ailelerin bir arada olması, engeller ya da sorunlara ilişkin kaynakların gözden geçirilmesi, paylaşılan duygu ya da değerleri güçlendirerek ailelerin dayanıklılık süreçlerine de olumlu katkı sağlamaktadır (4).

\title{
Aile Dayanıklılı̆̆ı ve Psikiyatri Hemşireliği Konusunda Yürütülen Araştırma Sonuçları
}

Tablo 2'de "aile dayanıklılığı ve ruhsal hastalıklar” konularında yürütülen araştırma örnekleri yer almaktadır (30-43). Bireysel dayanıklılıkla ilgili birçok araştırma literatürde yer alsa da bu derlemede doğrudan "aile dayanıklılığını" ele alan çalışmalara yer verilmiştir. İncelenen "ruhsal hastalıklar ve aile dayanıklılığı" araştırmalarının daha çok tanımlayıcı türde ve ailelerin dayanıklılık özelliklerine yönelik olduğu belirtilebilir. Ailelerde özellikle bir birey ruhsal hastalık tanısı aldığında bu durum bir kriz durumu olarak deneyimlenmektedir. Bu süreçte ailelerin dayanıklılık özellikleri ve bu özelliklerin geliştirilip iyileştirilmesi oldukça önemlidir (44). Ruhsal hastalık deneyimi olan bireylerde yapılan araştırmaların odak noktası daha çok ruhsal hastalıklarda aile dayanıklılı̆̆1, koruyucu faktörler, risk faktörleri veya ailenin bu konudaki deneyimlerine yöneliktir. Zauszniewski ve arkadaşları (2010) ağır ruhsal hastalığı olan bireylerin aile üyelerinin dayanıklılığını incelemiş olduğu derleme çalışmasında dayanıklılık özellikleri olarak umut, dayanıklı kişilik, öz-yeterlik, bütünlük duygusu gibi özellikleri belirtmiştir (44). Şizofreni tanılı 42 aile ile karma (miks) yöntem kullanılarak yapılan bir çalışmada da ailenin dayanıklılık özellikleri incelenmiştir. Çalışmanın sonucunda elde edilen dayanıklılık özellikleri; toplumsal ve ekonomik destek edinme, aile birlikteliği, kriz durumlarında iletişim biçimleri ve destekleyici iletişim tarzı, aile bağlılığı, krize meydan okuma ve ailenin iç kontrol odağ olarak saptanmıştır (30). Ruhsal hastalığa bakım veren dezavantajlı ailelerdeki aile dayanıklılık özelliklerini inceleyen başka bir kesitsel ve karma yöntem ile yapılan çalışmada ise kalitatif analizlerde dayanıklılık özellikleri üç geniş tema ile açıklanmıştır. $\mathrm{Bu}$ özellikler; evdeki duygusal fiziksel kaynakları içeren içsel kaynaklar, sosyal destek ve iletişim kaynakları gibi dışsal kaynaklar ve hasta ile ilişkili faktörlerdir (36). Tanımlayıcı araştırma sonuçlarından yola çıkılarak bir sistem olarak "ailelerde dayanıklılı̆̆ı" artırmaya yönelik psikososyal müdahaleleri içeren deneysel araştırmalara/müdahale araştırmalarına ihtiyaç bulunmaktadır.

\begin{abstract}
Sonuç
1970’li yıllardan bu yana aile dayanıklılığı konusunda teorik bir çerçeve oluşagelmiştir. Bu süreçte bakış açısı hastalıktan sağlığa, sorundan çözüme, bireyden aileye doğru bir gelişim sergilemiştir. Aile dayanıklılığı kavramı, her ailenin sorunları olduğu kadar kaynak ve güçlerinin de olduğunu fark etmek, ailenin yaşanan kriz durumlarından güçlenerek çıkmasının da mümkün olduğunu vurgulamak noktasında yeni bir bakış açısı kazandırmaktadır. Ailenin yaşamış olduğu güçlükler ile mücadelesinde anahtar dayanıklılık süreçlerinin kullanılarak krizin olumlu yönde bir uyuma dönüşmesi her aile için farklı biçimlerde deneyimlenen dinamik bir dayanıklılık yolculuğudur. Bu yolculuk sürecinde hasta /sağlıklı bireyler ve aileleri ile yakın iletişim halinde olan hemşirelerin ve psikiyatri hemşirelerinin aileleri değerlendirmeleri, ailelerin güçlü yönlerini desteklemeleri, gereksinimlerini belirlemeleri, gereksinim alanlarına göre müdahaleleri planlamaları önemlidir.
\end{abstract}

\section{Bilgilendirme}

Bu derlemede herhangi bir potansiyel çıkar çatışması bulunmamaktadır. Derlemede araştırma ve yayın etiğine uyulmuştur. Bu makalede yazar olarak listelenen herkes, çalışmaya doğrudan ve önemli katkıda bulunmuştur. 
Tablo 2. Ruhsal Hastalıklar ve Aile Dayanıklılığı Konusunda Yürütülen Araştırma Sonuçları

\begin{tabular}{|c|c|c|c|c|}
\hline No & Araştırma & Amaç & Yöntem & Sonuç \\
\hline 1. & $\begin{array}{l}\text { Bishop M, Greeff AP. Resilience in families in } \\
\text { which a member has been diagnosed with } \\
\text { schizophrenia. J Psychiatr Ment Health Nurs } \\
\text { 2015;22(7):463-471. }\end{array}$ & $\begin{array}{l}\text { Şizofreni tanılı aile üyesine sahip ailelerde } \\
\text { aile dayanıklılı̆̆ } 1 \text { özelliklerinin } \\
\text { belirlenmesidir. }\end{array}$ & $\begin{array}{l}\text { Kesitsel miks } \\
\text { yöntem }\end{array}$ & $\begin{array}{l}\text { Aile dayanıklılık özellikleri; ailenin ekonomik geliri, } \\
\text { toplumdan kazanılan destek, aile birlikteliği, kriz } \\
\text { durumlarında ailenin iletişim biçimi, destekleyici iletişim } \\
\text { örüntüleri, aileye bağlılık, krizlerin bir meydan okuma olarak } \\
\text { yeniden anlamlandırılması ve ailenin iç kontrol odağıdır. }\end{array}$ \\
\hline 2. & $\begin{array}{l}\text { Faqurudheen H, Mathew S, Kumar TM. } \\
\text { Exploring family resilience in a community } \\
\text { mental health setup in south India. Procedia } \\
\text { Economics and Finance 2014;18:391-399. }\end{array}$ & $\begin{array}{l}\text { Bir toplum ruh sağllğı biriminde tedavi alan } \\
\text { danışanların ve bakım verenlerinin sosyo- } \\
\text { demografik özellikleri ve aile dayanıklılık } \\
\text { düzeyinin belirlenmesidir. }\end{array}$ & $\begin{array}{l}\text { Tanımlayıcı } \\
\text { yöntem }\end{array}$ & $\begin{array}{l}\text { Bireylerin dayanıklılıkları orta düzeyden yüksek düzeye } \\
\text { doğru değişmektedir. }\end{array}$ \\
\hline 3. & $\begin{array}{l}\text { Fitryasari R, Yusuf A, Tristiana RD, Nihayati } \\
\text { HE. Family members' perspective of family } \\
\text { Resilience's risk factors in taking care of } \\
\text { schizophrenia patients. Int J Nurs Sci } \\
\text { 2018;5(3):255-261. }\end{array}$ & $\begin{array}{l}\text { Şizofreni hastasına bakım veren bireylerin } \\
\text { dayanıklılık risk faktörlerinin } \\
\text { tanımlanmasıdır. }\end{array}$ & $\begin{array}{l}\text { Kalitatif } \\
\text { yöntem } \\
\text { (fenomenoloji) }\end{array}$ & $\begin{array}{l}\text { Risk faktörü olarak iki tema elde edilmiştir. Bunlar; bakım } \\
\text { yükü ve damgalamadır. }\end{array}$ \\
\hline 4. & $\begin{array}{l}\text { Fitryasari R, Yusuf A, Nursalam R, Tristiana D, } \\
\text { Hargono R. Resiliency experiences of family } \\
\text { members who take care of patients with } \\
\text { schizophrenia. Proceedings of the 9th } \\
\text { International Nursing Conference (INC); } 2018 .\end{array}$ & $\begin{array}{l}\text { Şizofreni hastasına bakım veren bireylerin } \\
\text { bakış açısından aile dayanıklılığının } \\
\text { tanımlanmasıdır. }\end{array}$ & $\begin{array}{l}\text { Kalitatif } \\
\text { yöntem } \\
\text { (fenomenoloji) }\end{array}$ & $\begin{array}{l}\text { Şizofreni hastasına primer bakım veren bireyler beş aşamalı } \\
\text { bir yoldan dayanıklılık süreci tanımlamıştır. Bu aşamalar; } \\
\text { mevcut durumla mücadele, aile yapısının değişimi, hasta aile } \\
\text { üyesini kabul etmeye çalışmak, olumlu bir anlam arayışı ve } \\
\text { ailede yer alan diğer bireylere destek sağlamaktır. }\end{array}$ \\
\hline 5. & $\begin{array}{l}\text { Fitryasari R, Nursalam N, Yusuf A, Hargono R, } \\
\text { Lin ECL, Tristiana RD. Development of a } \\
\text { family resiliency model to care of patients with } \\
\text { schizophrenia. Scand J Caring Sci 2020:1-8 }\end{array}$ & $\begin{array}{l}\text { Şizofreni hastasına bakım verenlerde aile } \\
\text { merkezli hemşireliğe temelli aile } \\
\text { dayanıklılık modeli geliştirmektir. }\end{array}$ & $\begin{array}{l}\text { Kesitsel miks } \\
\text { yöntem }\end{array}$ & $\begin{array}{l}\text { Ailenin risk faktörleri, koruyucu faktörler ve ailenin } \\
\text { stresinden etkilenmektedir. Aile dayanıklılığı ailelerin } \\
\text { hastasının bakım ve tedavi etme becerilerini etkilemektedir. } \\
\text { Model ailelerin hastasına daha iyi bakım vermesi ve } \\
\text { güçlenmesi noktasında yardımcı olmaktadır. }\end{array}$ \\
\hline 6. & $\begin{array}{l}\text { Greeff AP, Vansteenwegen A, Ide M. Resiliency } \\
\text { in families with a member with a psychological } \\
\text { disorder. Am J Fam Ther 2006;34(4):285-300. }\end{array}$ & $\begin{array}{l}\text { Ruhsal hastalığı olan ailelerde dayanıklılık } \\
\text { faktörlerinin tanımlanmasıdır. }\end{array}$ & $\begin{array}{l}\text { Kesitsel ilişki } \\
\text { arayıcı yöntem }\end{array}$ & $\begin{array}{l}\text { Ailelerin tanımlamış oldukları dayanıklılık faktörleri, aile ve } \\
\text { toplumdan edinilen kaynaklar ve başetme becerileridir. En } \\
\text { önemli dayanıklılık faktörü ise hem hasta birey hem aile } \\
\text { üyeleri tarafindan belirtilen (hardiness) dayanıklılık } \\
\text { özelliğidir. }\end{array}$ \\
\hline 7. & $\begin{array}{l}\text { Jonker L, Greeff AP. Resilience factors in } \\
\text { families living with people with mental } \\
\text { illnesses. J Community Psychol 2009;37(7):859- } \\
873 .\end{array}$ & $\begin{array}{l}\text { Yoksul bir bölgede yaşayan, ruhsal } \\
\text { hastalığı olan bireye bakım veren ailelerde } \\
\text { dayanıklılık faktörlerini belirlemek. }\end{array}$ & $\begin{array}{l}\text { Kesitsel miks } \\
\text { yöntem }\end{array}$ & $\begin{array}{l}\text { Din ve maneviyat ve bireysel aile üyelerinin kişisel } \\
\text { özellikleri en yaygın olarak belirtilen dayanıklılık faktörleri } \\
\text { olarak bulunmuştur. }\end{array}$ \\
\hline 8. & $\begin{array}{l}\text { Mahmoud S. Association between burden of } \\
\text { care and resilience among family caregivers } \\
\text { living with schizophrenic patients. IOSR Journal } \\
\text { of Nursing and Health Science 2011;7(2):42-55. }\end{array}$ & $\begin{array}{l}\text { Şizofreni tanılı bireylerin bakım } \\
\text { verenlerinin bakım yükü, aile işlevselliği ve } \\
\text { dayanıklılık düzeyleri arasındaki ilişkiyi } \\
\text { değerlendirmek. }\end{array}$ & $\begin{array}{l}\text { Tanımlayıcı } \\
\text { ilişki arayıcı } \\
\text { yöntem }\end{array}$ & $\begin{array}{l}\text { Aile işlevselliği ve dayanıklılık arasında pozitif yönde bir } \\
\text { ilişki olduğu bulunmuştur. }\end{array}$ \\
\hline
\end{tabular}




\begin{tabular}{|c|c|c|c|c|}
\hline 9. & $\begin{array}{l}\text { Marsh DT, Lefley HP, Evans-Rhodes D, Ansell } \\
\text { VI, Doerzbacher BM, LaBarbera L, Paluzzi JE. } \\
\text { The family experience of mental illness: } \\
\text { evidence for resilience. Psychiatr Rehabil J } \\
\text { 1996;20(2):3. }\end{array}$ & $\begin{array}{l}\text { Ruhsal hastalıkta aile deneyimlerinin } \\
\text { incelenmesidir. }\end{array}$ & Tanımlayıcı & $\begin{array}{l}\text { Aile dayanıklılığın boyutları aile bağları, ailenin güçlü } \\
\text { yönleri ve kaynakları, ailenin gelişimi ve ailenin } \\
\text { memnuniyeti olarak belirlenmiştir. }\end{array}$ \\
\hline 10. & $\begin{array}{l}\text { Power J, Goodyear M, Maybery D, Reupert A, } \\
\text { O’Hanlon B, Cuff R, Perlesz A. Family } \\
\text { resilience in families where a parent has a } \\
\text { mental illness. J Soc Work 2016;16(1):66-82. }\end{array}$ & $\begin{array}{l}\text { Araştırmada ebeveynin ruhsal hastalı̆̆ } \\
\text { olduğu ailelerde aile dayanıklılığının nasıl } \\
\text { olduğunun kavramsallaştırılmasıdır. }\end{array}$ & Kalitatif & $\begin{array}{l}\text { Ailede paylaşılan mizah ve aile rutinleri süreçleriyle aileler } \\
\text { dayanıklılık geliştirmektedirler. Aile için dayanıklılık, } \\
\text { distres/stres ile güç arasındaki dengeyi sağlamakla } \\
\text { ilişkilendirilmiştir. }\end{array}$ \\
\hline 11. & $\begin{array}{l}\text { Han KS, Hong YS, Kang H, Roh YH, Choi MS, } \\
\text { Moon HJ. Developing a prediction model for } \\
\text { family health in families of patients with } \\
\text { schizophrenia. Journal Of Korean Academy of } \\
\text { Psychiatric and Mental Health Nursing } \\
\text { 2020;28(4):309-320. }\end{array}$ & $\begin{array}{l}\text { Bu çalışmanın amacı, aile sağlığı ile ilgili } \\
\text { faktörleri belirlemek ve şizofreni } \\
\text { hastalarının ailelerinde aile sağlığını } \\
\text { açıklayabilecek bir öngörü modeli } \\
\text { geliştirmektir. }\end{array}$ & Tanımlayıcı & $\begin{array}{l}\text { Aile dayanıklılığının, benlik saygısının ve toplum } \\
\text { entegrasyonunun şizofreni tanılı bireylerin aile sağlığı } \\
\text { üzerinde olumlu ve doğrudan etkileri bulunmaktadır. }\end{array}$ \\
\hline 12. & $\begin{array}{l}\text { Weine S, Ukshini S, Griffith J, Agani F, } \\
\text { Pulleyblank-Coffey E, Ulaj J ve ark. A family } \\
\text { approach to severe mental illness in post-war } \\
\text { Kosovo. Psychiatry 2005;68(1):17-27. }\end{array}$ & $\begin{array}{l}\text { Birinci amaç; ailelerini topluma dayalı } \\
\text { destek hizmetlerine katılmaları için } \\
\text { harekete geçirerek ruhsal hastalığı olan } \\
\text { kişilere toplum temelli bakım sunmaktır. } \\
\text { İkinci amaç aile temelli becerileri } \\
\text { profesyonel yaşamda uygulamak için ruh } \\
\text { sağlığı uzmanlarının eğitilmesidir. Bu } \\
\text { amacı gerçekleştirmek için psikoeğitimsel } \\
\text { çoklu aile grup müdahaleleri } 30 \text { aileye } \\
\text { uygulanmıştır. }\end{array}$ & $\begin{array}{l}\text { Müdahale } \\
\text { araştırması }\end{array}$ & $\begin{array}{l}\text { Çoklu aile grubunun aile yaşamı üzerinde umudu artırmak, } \\
\text { ruhsal hastalıktan dolayı aile üyesini suçlamayı azaltmak, } \\
\text { başetme becerilerini ve yaşam kalitesini artırmak gibi birçok } \\
\text { olumlu etkisinin olduğu bulunmuştur. }\end{array}$ \\
\hline 13. & $\begin{array}{l}\text { Zerbetto SR, Galera SAF, Ruiz BO. Family } \\
\text { resilience and chemical dependency: perception } \\
\text { of mental health professionals. Rev Bras } \\
\text { Enferm 2017;70(6): 1184-1190. }\end{array}$ & $\begin{array}{l}\text { Bağımlılık biriminde çalışan sağlık } \\
\text { profesyonellerinin ailelerin dayanıklılık } \\
\text { özelliklerine ilişkin algılarını } \\
\text { tanımlamaktır. }\end{array}$ & $\begin{array}{l}\text { Tanımlayıc1 } \\
\text { kalitatif }\end{array}$ & $\begin{array}{l}\text { Araştırmada odak grup görüşmeleri ile elde edilen veriler } \\
\text { doğrultusunda üç tema elde edilmiştir. Bu temalar etkili } \\
\text { iletişim; liderlik ve desteğin rolü ve ailenin gücüdür. Sağlık } \\
\text { profesyonelleri ortam/durum çok gergin bile olsa dayanıklı } \\
\text { ailelerin mesajlarını karşı tarafa açık, sakin bir şekilde } \\
\text { ilettiklerini belirtmiştir. }\end{array}$ \\
\hline 14. & $\begin{array}{l}\text { Saul J, Simon W. Building resilience in } \\
\text { families, communities, and organizations: A } \\
\text { training program in global mental health and } \\
\text { psychosocial support. Fam Process } \\
\text { 2016;55(4):689-699. }\end{array}$ & $\begin{array}{l}\text { Ciddi olumsuzluklara ve travmalara maruz } \\
\text { kalan topluluklarla çalışan profesyoneller } \\
\text { için bir program tanıtımını açıklamaktadır. }\end{array}$ & & $\begin{array}{l}\text { Araştırmanın odak noktası olan ilk modül güçlüklere maruz } \\
\text { kalan aile ve toplumlarda dayanıklılığı artırmak için } \\
\text { yaklaşımları ögretmeyi içermektedir. Katılımcılarla her gün } \\
\text { ortak kaynaklarını ve öğrenme deneyimini geliştirme } \\
\text { yöntemlerini güçlendirmek için egzersizler yapılmıştır. }\end{array}$ \\
\hline
\end{tabular}




\section{Kaynaklar}

1. Black K, Lobo M. A conceptual review of family resilience factors. J Fam Nurs 2008;14(1):33-55.

2. Patterson JM. Integrating family resilience and family stress theory. J Marriage Fam 2002;64(2):349-360.

3. Rutter M. Resilience: some conceptual considerations. Journal of Adolescent Health 1993;14(8):626-631.

4. Walsh F. The concept of family resilience: crisis and challenge. Fam Process 1996;35(3):261-281.

5. Walsh F. Family resilience: a framework for clinical practice. Fam Process 2003;42(1):1-18.

6. Masten AS, Cicchetti D. Resilience in development: progress and transformation. Dev Psychopathol 2016;1-63.

7. Masten AS, Powell L. A resilience framework for research, policy and practise. İçinde Luthar SS Resilience and Vulnerability: Adaptation in the Context of Childhood Adversities. Cambridge University Press; 2003:1-25.

8. Walsh F. A Family developmental framework challenges and resilience across the life cycle. İçinde Sexton T \& Lebow J, Handbook of Family Therapy, Routledge; 2015: 30-47.

9. Simon JB, Murphy JJ, Smith SM. Understanding and fostering family resilience. The Family Journal 2005;13(4):427-436.

10. Hawley DR. Clinical implications of family resilience. Am J Fam Ther 2000;28(2):101-116.

11. Van Breda AD. Resilience theory: A literature review. South Africa; 2001.

12. McCubbin HI, Patterson JM. The family stress process: The double ABCX model of adjustment and adaptation. Marriage Fam Rev 1983;6(1-2):7-37.

13. Çetinkaya Duman Z. Çocuk ergen ruh sağlığı ve psikiyatri hemşireliğinde aile temelli yaklaşım. Türkiye Klinikleri 2015;1(2):92-99.

14. Maurović I, Liebenberg L, Ferić M. A review of family resilience: understanding the concept and operationalization challenges to inform research and practice. Child Care Pract 2020;26(4):337-357.

15. Henry CS, Sheffield Morris A, Harrist AW. Family resilience: moving into the third wave. Fam Relat 2015;64(1):22-43.

16. Coleman M, Ganong L. Resilience and families. Fam Relat 2002;51(2):101.

17. Walsh F. Strengthening Family Resilience. 2. Basım. Walsh F. Guilford Publications; 2006.

18. Von Bertalanffy L. General System Theory: Foundation, Development, Application. New York, NY: Braziller 1968.

19. Masten AS. Resilience theory and research on children and families: Past, present, and promise. J Fam Theory Rev 2018;10(1):12-31.

20. Walsh F. Family resilience: a developmental systems framework. Eur J Dev Psychol 2016a;13(3):313-324.

21. Oh S, Chang SJ. Concept analysis: family resilience. Open J Nurs 2014;4(13):980.

22. Walsh F. Applying a family resilience framework in training, practice, and research: mastering the art of the possible. Fam Process 2016b;55(4):616-632.

23. Patterson JM. Understanding family resilience. J Clin Psychol 2002;58(3):233-246.

24. Walsh F. Family resilience: strengths forged through adversity. İçinde Walsh F, Normal Family Process. 4. Baskı. Guildford Press; 2012:399-427.

25. Walsh F. Traumatic loss and majör disasters: strengthening family and community resilience. Fam Process 2007;46(2):207227.

26. Walsh F. Community-based practice applications of a family resilience framework. İçinde Becvar DS, Handbook of Family Resilience. Springer; 2013: 65-82.

27. Bademli K, Duman Çetinkaya Z. Ruhsal hastalık tanılı bireylerde aile ile işbirliğini başlatma ve sürdürmede psikiyatri hemşireliği. Türkiye Klinikleri Psychiatric Nursing-Special Topics 2018;4(1):21-26.

28. Bademli K, Duman Çetinkaya Z. Effects of a family-to-family support program on the mental health and coping strategies of caregivers of adults with mental illness: a randomized controlled study. Arch Psychiatr Nurs 2014;28(6):392-398.

29. Duman Çetinkaya Z, Bademli K. Şizofreni hastalarının bakım verenlerine uygulanan aileden aileye destek programları. Dokuz Eylül Üniversitesi Hemşirelik Fakültesi Elektronik Dergisi 2011;4(4):178-181.

30. Bishop M, Greeff AP. Resilience in families in which a member has been diagnosed with schizophrenia. J Psychiatr Ment Health Nurs 2015;22(7):463-471.

31. Faqurudheen H, Mathew S, Kumar TM. Exploring family resilience in a community mental health setup in south India. Procedia Economics and Finance 2014;18:391-399.

32. Fitryasari R, Yusuf A, Tristiana RD, Nihayati HE. Family members' perspective of family resilience's risk factors in taking care of schizophrenia patients. Int J Nurs Sci 2018;5(3):255-261.

33. Fitryasari R, Yusuf A, Nursalam R, Tristiana D, Hargono R. Resiliency experiences of family members who take care of patients with schizophrenia. Proceedings of the 9th International Nursing Conference (INC 2018); 2018.

34. Fitryasari R, Nursalam N, Yusuf A, Hargono R, Lin ECL, Tristiana RD. Development of a family resiliency model to care of patients with schizophrenia. Scand J Caring Sci 2020:1-8

35. Greeff AP, Vansteenwegen A, Ide M. Resiliency in families with a member with a psychological disorder. Am J Fam Ther 2006;34(4):285-300.

36. Jonker L, Greeff AP. Resilience factors in families living with people with mental illnesses. J Community Psychol 2009;37(7):859-873.

37. Mahmoud S. Association between burden of care and resilience among family caregivers living with schizophrenic patients. IOSR Journal of Nursing and Health Science 2011;7(2):42-55.

38. Marsh DT, Lefley HP, Evans-Rhodes D, Ansell VI, Doerzbacher BM, LaBarbera L ve ark. The family experience of mental illness: evidence for resilience. Psychiatr Rehabil J 1996;20(2):3.

39. Power J, Goodyear M, Maybery D, Reupert A, O’Hanlon B, Cuff R ve ark. Family resilience in families where a parent has a mental illness. J Soc Work 2016;16(1):66-82. 
40. Han KS, Hong YS, Kang H, Roh YH, Choi MS, Moon HJ. Developing a prediction model for family health in families of patients with schizophrenia. Journal of Korean Academy of Psychiatric and Mental Health Nursing 2020;28(4):309-320.

41. Weine S, Ukshini S, Griffith J, Agani F, Pulleyblank-Coffey E, Ulaj J ve ark. A family approach to severe mental illness in post-war Kosovo. Psychiatry 2005;68(1):17-27

42. Zerbetto SR, Galera SAF, Ruiz BO. Family resilience and chemical dependency: perception of mental health professionals. Rev Bras Enferm 2017;70(6):1184-1190.

43. Saul J, Simon W. Building resilience in families, communities, and organizations: A training program in global mental health and psychosocial support. Fam Process 2016;55(4):689-699.

44. Zauszniewski JA, Bekhet AK, Suresky MJ. Resilience in family members of persons with serious mental illness. Nursing Clinics 2010;45(4):613-626. 